\title{
Internationalizing The Business Curriculum: A South Korean Case Study
}

Robin Self, Alabama State University, USA

Donald R. Self, Auburn University Montgomery, USA

\begin{abstract}
Accrediting agencies for Colleges and Schools of Business such as the Association to Advance Collegiate Schools of Business International (AACSB) and the Association of Collegiate Business Schools and Programs (ACBSP) require that business programs incorporate both an international dimension and an active learning component in developing their business curriculum. One avenue business schools can use to accomplish both of these goals is to provide abbreviated study abroad programs for students and faculty. Rather than spending an entire semester abroad (which many smaller schools cannot afford to do financially), one approach is to take $10-15$ students and spend $7-10$ days in a country. This paper presents one case study using this approach - An 8 day Study Abroad Trip to South Korea - and discusses the following areas: logistics, pre-trip preparation, trip activities, and post-trip activities. While this case study focuses on South Korea, it provides a model for international study abroad that helps business schools meet accreditation standards and internationalize their curriculum.
\end{abstract}

Keywords: South Korea, business curriculum, accreditation, Hofstede, cultural dimensions, study abroad

\section{INTRODUCTION}

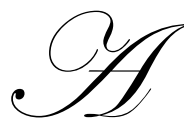

ccrediting agencies for Colleges and Schools of Business such as the Association to Advance Collegiate Schools of Business International (AACSB) and the Association of Collegiate Business Schools and Programs (ACBSP) require that business programs incorporate both an international dimension and an active learning component in developing their business curriculum.

First, the international dimension is addressed by the AACSB's Standard 15 (Management of Curricula) which includes the importance of "multicultural and diversity understanding" and understanding "the domestic and global economic environment of organizations" (AACSB International Eligibility Procedures and Accreditation Standards for Business Accreditation, 2008, p. 15). Standard 6.1.3 (Common Professional Component) of the ACBSP standards includes the "global dimension of business" and includes the importance of globalization in its mission statement: "ACBSP focuses on providing leadership to develop global alliances for improving business curricula throughout the world" (ACBSP Standards and Criteria for Demonstrating Excellence in Baccalaureate/Graduate Degree Schools and programs, 2008, p. 39).

The second area of significance concerns incorporating active learning and problem solving skills. Standard 13 of the AACSB standards focuses on "actively engaging students in the learning process" and "engaging in collaborative learning experiences" (p. 14). Standard 6.1.4 of the ACBSP addresses curriculum design "to focus on students' active learning for the development of problem solving skills" (p. 46).

One avenue business schools can use to accomplish both of these goals is to provide abbreviated study abroad programs for students and faculty. Because smaller schools may have fewer funds, rather than spending an entire semester abroad, one approach is to take $10-15$ students and spend $7-10$ days in a country. This paper presents one case study using this approach - An 8 day Study Abroad Trip to South Korea - and is divided into the following sections: logistics, pre-trip preparation, trip activities and post-trip activities. While this case study 
focuses on South Korea, it provides a model for international study abroad that helps business schools meet accreditation standards and internationalize their curriculum.

\section{LOGISTICS}

Logistics concerns trip funding, site selection, scheduling and transportation, passport and visa requirements, vaccines and health risks, institutional requirements, and cell phones.

\section{Funding}

Of major concern to most colleges and universities is funding for an international study abroad trip. Funding typically takes the form of university sponsored funding through internal faculty development grants, tuition, and other institutional specific sources. Outside funding, such as Title III grants, is also available for institutions meeting certain criteria, such as being an Historically Black College or University. Business schools may also partner with different academic areas (foreign languages, art or literature) or the business community in order to qualify for more specific funding opportunities. The U. S. Department of Education offers grant opportunities for international curriculum development through Title VI. Specific funding sources are identified below:

- Title VI Higher Education Act: Under Title VI of the Higher Education Act, IEGPS (International Education and Graduate Programs Service) in the office of Postsecondary Education supports ten programs, both for individuals and for institutions of higher education. While the National Resource Centers (NRCs), Foreign Language and Area Studies Fellowships (FLAS), and International Research and Studies (IRS) are the central programs in Title VI, Title VI also supports seven distinct yet interrelated programs. These include the Undergraduate International Studies and Foreign Language Program (UISFL); The Business and International Education Program (BIE); Centers for International Business Education (CIBS); Language Resource Centers (LRCs); American Overseas Research Centers (AORCs); the Institute for International Public Policy (IIPP); and the Technological Innovation and Cooperation for Foreign Information Access Program (TICFIA). Links to detailed information about these programs and the application process can be found at http://www.ed.gov/about/offices/list/ope/iegps/ (Title VI, 2008).

- $\quad$ Title VI A: Undergraduate International Studies and Foreign Language Program (UISFL): This program provides funds to institutions of higher education, a combination of such institutions, or partnerships between nonprofit education organizations and institutions of higher education to plan, develop and carry out programs to strengthen and improve undergraduate instruction in international studies and foreign languages.

- $\quad$ Title VI B: Business and International Education Program (BIE). This program provides matching grants to colleges and universities to internationalize the business curriculum and to promote links between academic institutions and the American business community. There are two requirements: You must improve the academic teaching of the business curriculum and conduct outreach activities that expand the capacity of the business community to engage in international economic activities. While Centers for International Business Education (CIBES) tend to be located at major universities, BIE funds usually enhance internationalization of business education and area businesses at smaller four-year institutions, community and two year colleges. BIE grantee institutions host a joint Web site at http://www/.docp.wright/edu/bie/ (Title VI, 2008).

Santa Fe Community College, the University of Pittsburg, and California College of International Education have all received Title VI B grants and have information about the grants on the following websites: http:inst.sfcc.edu/\%7Eied/, http://www.business.pitt.edu/ibc/academics/curriculum-developmentgrant.php, http://ccieworld.org/curriculum.htm.

- $\quad$ NAFSA's Cooperative Grant Program (COOP) from the Bureau of Educational and Cultural Affairs of the U. S. Department of State funds enrichment programming which encourages interaction and promotes 
better understanding between international students, their American peers, faculty and communities as well as programming which enhances the experience of American education abroad students. (See NAFSA's website Cooperative Grant Program which funds the Incentive Grant, and the mini grants Webmaster@nafsa.org).

- $\quad$ FIPSE (Fund for Improvement of Postsecondary Education): FIPSE accepts proposals for international education and has four specific international programs: U.S. Brazil Higher Education Consortia Program, European Union-United States Atlantis Program, Program for North American Mobility in Higher Education (focuses on creating an alliance of two American, two Canadian and two Mexican universities), and the U.S. -Russia Program. See http://www.ed.gov/about/offices/list/ope/fipse/index.html for program information (FIPSE Home Page, 2009).

- $\quad$ Fulbright Hays Groups Abroad Program: Under the Fulbright Hays Act, the International Education and Graduate Programs Service provides a variety of grants to individuals and institutions of higher education for projects in modern foreign languages and area studies. Contact Lungching Chiao (lungching.chiao@ed.gov) for "Group Projects Abroad.”

See "Funding Sources for International Business" by Steven Loughrin Sacco for additional insights at www.cudenver.edu/International/CIBER/Documents/Funding.

\section{Site Selection}

When selecting a country to visit, two factors should be considered. First, do you or the institution have local contacts at the host country to facilitate local arrangements? Second, what are the linkages of your institution, community, state or region to the host country which would facilitate incorporating both cultures into the classroom curriculum? These could be cultural, manufacturing, etc. For example, South Korea was selected for our study abroad program because of linkages with a South Korean University, government official, and business ties (Hyundai and Kia have manufacturing plants located in the University's region, which draw in Tier 1, 2 and 3 suppliers as well).

\section{Scheduling and Transportation}

Typically one individual at the institution sponsoring the trip will be responsible for all arrangements including air travel, hotel accommodations in the country, travel throughout the country, and transportation to and from the airport. Most arrangements can be made through the internet and are typically straight forward. This process is greatly facilitated if the institution has a host facilitator to handle accommodations, tours, etc., in the host country. This individual can serve as translator, local coordinator and contact person.

\section{Passport and Visa Requirements}

Depending upon your student population, many students may not have traveled outside of the United States and will need to apply for a passport. The U.S. State Department of Passport Office offers downloadable application forms and passport information at their website: http://travel.state.gov/passport/index.html. Make sure students apply for passports at least 6-8 weeks prior to the travel study departure date. If this is not possible, passports can be expedited for an additional fee (The current total passport fee for persons aged 16 and older is \$97). Although Korea does not require visas from United States citizens you can check your host country's entry requirements for travel study at http://travel.state.gov/travel/tips/brochures/brochures_1229.html.

\section{Vaccines and Health Risks}

Although vaccines were not necessary for Korea, you need to find out if there are any required or recommended vaccines for your host country. Faculty can check the Centers for Disease Control (CDC) website at www.cdc.gov.travel for required vaccines. If needed, allow for 3 months lead time, prior to departure, for travelers 
to get the necessary vaccines for Hepatitis A, B, Yellow Fever, Diphtheria, Typhoid Fever, Malaria, etc. You can also research information about your host country at the CDC's website (SIUE Travel Abroad, 2009).

\section{Institutional Requirements}

All educational institutions will have requirements for international travel (for both students and faculty) that will vary by institution. Check with your administration to secure the appropriate forms and specific requirements. For example, many colleges and universities require that all travel study participants must purchase the ISIC (International Student Identity Card) which provides overseas accident and medical insurance, and emergency medical evacuation coverage through Travel Guard Insurance. The cost of the ISIC card is $\$ 22$. The ISIC can be purchased online at www.myisic.com. Your institution may also require that you register with the U.S. Department of State Travel Registration, a free service provided by the U. S. government to U.S. citizens who are traveling to a foreign country. The online registration process lets you record information about upcoming travel abroad that the State Department can use in case of an emergency to locate U. S. citizens. Go to https://travelregistration.state.gov/ibrs/ to register (SIUE Travel Abroad, 2009).

\section{Cell phones}

This generation of students likes to stay connected, regardless of their location. Students need to check with their cell phone carrier to make sure their phone has the capability to send/receive internal calls/text in the host country. Students should also find out the rates for phone and texting prior to leaving the country. Outside of the United States and a handful of countries, international cell phone carriers operate on a unified standard called GSM (Global Services for Mobile). This GSM standard requires a GSM mobile phone and a SIM (Subscriber Identity Module) card. The SIM card is part of a removable smart card ICC (Integrated Circuit Card) that allows your phone to connect with a local wireless carrier in the country you are visiting. If you want an international cell phone service, you will need a phone that is GSM compatible and SIM-unlocked. An often described global phone, travel mobile, travel phone or world phone is merely a GSM mobile phone that operates on the 900, 1800 and 1900 frequencies. If the world phone is unlocked it will work with any prepaid SIM card in Europe.

Southern Illinois University Edwardsville has information checklists available on their website for faculty preparing to take students abroad, and for student checklists as well. The Student Checklist includes the following information: general travel information, health and safety abroad, health insurance, country specific information, passports and visas, money matters, information about the U.S. State Department, and foreign embassies. Please see http://www.siue.edu/international/octravel/Checklist.shtml for additional information. Other institutions offering additional insight and specifics include The University of Kansas (http://www.kumc.edu/international/travel_checklist.html), and Capital University (http://oldsite.capital.edu/facultystaff/international-travel.html).

\section{PRE-TRIP ACTIVITIES}

To ensure the best educational experience possible, prior to the trip, students should be exposed to the host country's culture, basic business etiquette, language, and the economy. This can be accomplished through pairing with other academic units on campus (languages, communication departments, etc.), through workshops with business and community leaders who have expertise in the host country's practices, and from utilizing international faculty members' expertise.

\section{Culture}

Elements of the host culture that students should be aware of include the following: geography, people, government, and history. The following information presents a summary of what students learned about Korea prior to the trip.

- Geography: South Korea covers 98,480 square kilometers (slightly larger than Indiana). The terrain is partially forested mountain ranges separated by deep, narrow valleys with cultivated plains along the 
coasts, particularly in the west and south. Seoul is the capital with 10.3 million people (2005). Other major cities include Busan (3.7 million), Daegu (2.5 million), Incheon (2.6 million) and Ulsan (1 million) (South Korea, 2008). Students were exposed to the relationship between the geography of South Korea and the development and growth of Korean industries.

- People: With a population in 2008 of $48,379,392$ people, Korea is one of the most ethnically and linguistically homogenous nations in the world. Except for a small Chinese community (roughly 20,000), virtually all Koreans share a common culture and linguistic heritage. The language is Korean and English is widely taught in junior high and high school. The religions in Korea consist of Christianity, Buddhism, Shamanism, Confucianism, and Chondogyo (South Korea, 2008)

- $\quad$ Government: Korea is a republic with power shared among the president, the legislature and the courts. They were liberated August 15, 194,5 and the constitution was last revised in 1987. There are nine provinces and seven administratively separate cities (Seoul, Busan, Incheon, Daegu, Gwangju, Daejeon, Ulsan). The central government budget expenditures for 2007 were $\$ 256.6$ billion (South Korea, 2008).

- $\quad$ Abbreviated History: The myth of Korea's foundation by the god-king Tangun in BC 2333 typifies the homogeneity and self-sufficiency valued by the Korean people. Korea had many invasions by its larger neighbors in its 2,000 years of recorded history. In 1910, Japan began a 35-year period of colonial rule over Korea. As a result of Japan's attempts to supplant the Korean language and aspects of Korean culture, memories of Japanese annexation still cause animosity and resentment among many, particularly older Koreans. On August 15, 1948, the Republic of Korea was established (South Korea, 2008).

\section{Business Etiquette}

Important elements of the host country's business etiquette include the following: Greetings and Introductions, Gift-Giving, Business Card Exchange, Business Meetings, Business Conversation, Social Interaction, Drinking Etiquette, and Table Manners.

While the following list is not exhaustive, this is a sampling of what students were exposed to concerning Korean etiquette:

- $\quad$ Greetings \& Introductions: You should usually address your Korean counterpart by his job position/title and last name. When two Koreans have the same last name, they may distinguish each other by their initials. In that case, insert their initials before their last name. For example, Manager F. G. Park and Manager R. T Park.

When meeting a man, it is customary to greet with a handshake. If you want to add more respect to your shake, bring the left hand over your counterpart's right hand. You may also combine the handshake with a bow. Women will be expected to greet with a handshake, too (Bammel, 2003a)

- Gift Giving: Gifts are always appreciated. Consider taking a small momento that represents your hometown to your hosts. While the gift should not be overly expensive, it should not be cheap.

Don't be surprised if your hosts have a Korean gift for you. If the gift is wrapped, don't open it until you leave. If the gift is unwrapped, make sure to express expression and ask questions about the gift to show interest (whether you like it or not).

Gifts should be given with the right hand or both hands and received the same way. Treat the gift with reverence and care and don't set the gift on the floor - leave it on the table or put it in your briefcase/bag (Bammel, 2003b). 
- $\quad$ Business Card Exchange: Cards are exchanged at the beginning of the meeting so make sure you have enough to give one to everyone. Take more business cards with you than you would on a trip within the United States. Be sure to stand up when exchanging cards with those of higher rank.

Facing your counterpart, bow slightly and hand your card (with the Korean-language side up) either with your right hand or both hands. Do the same when receiving a card (Bammel, 2003c).

- $\quad$ Business Meetings: Casual Western attire is still uncommon in the Korean business place. Dress appropriately for the occasion when meeting your counterparts on business.

Seating protocol during business meetings will be determined by the status of participants. Wait to be directed to the appropriate seat rather than just sitting down. As a general rule, the highest ranking person on the host's side will sit at the head of the table. As a rule, those of higher status sit closest to the highest ranking individual (Bammel, 2003d).

- $\quad$ Business Conversation: Koreans may ask you questions that may make you uncomfortable, such as asking your age, or marital status. Some questions you would consider rude in your home culture are not considered impolite in Korea. Koreans enjoy talking about their country and famous locations. You are not expected to greet people that you don't know. Whereas North Americans are likely to say hello to strangers in the office, Koreans may ignore almost anyone they don't know (Bammel, 2003e).

- Social Interaction. If you go to dinner, "going Dutch" is not normal in Korea. If you are the customer, you will likely be in for a free evening of entertainment. If you are the vendor, expect to pick up the bill.

Koreans are unlikely to invite you into their homes. It is normal for dinner meetings to be held in restaurants. Tipping is not customary in Korea and you do not have to do it (Bammel, 2003f).

- $\quad$ Drinking Etiquette. Many Koreans like to drink alcohol during and after dinner. If you don't drink, at least accept the beverage and look like you are sipping. If drinking is out of the question, explain that for health or religions reasons you are not able to accept the beverage.

Always request a cup or glass rather than drinking from a bottle. Recognize that metal cups are for water.

Never pour your own drink. Instead, take the initiative and pour your counterpart's beverage. Make the bottle available for the other person to pour your drink (Bammel, 2003g).

- Table Manners: Meals are usually eaten with chopsticks and a spoon (used for eating rice). The best way to learn what is appropriate is to watch your host.

When eating with your hosts, try to taste a little of each food. Many popular restaurants involve sitting on the floor around a low table. If you aren't sure whether you can handle this comfortably, be sure to tell your hosts in advance so they can request an ordinary table (Bammel, 2003, h).

\section{Language}

Students should learn the basic greetings and common phrases of the host country. If the foreign language department on campus is not able to offer workshops or instruction, students can refer to guide books and tapes to familiarize themselves with the necessary expressions.

\section{Economy}

When studying the host country's economy, students should be familiar with the following information: GDP, GDP growth rate, per capita GNI, consumer price index, natural resources, industries, trade, currency, and composition of work force. 
Students learned the following information about the Korean economy:

- $\quad$ South Korea has been experiencing economic growth since the late 1960s

- $\quad$ South Korea's GDP (purchasing power parity in 2007): $\$ 1,201$ trillion

- $\quad$ GDP growth rate: 2004, 4.7\%; 2005, 4.2\%; 2006, 5.1\%, 2007, 5.0\%

- $\quad$ Per capita GNI (2007): $\$ 20,045$

- $\quad$ Consumer price index: 2004, 3.6\%; 2005, 2.8\%; 2006, 2.2\%; 2007, 2.5\%

- Natural resources: coal, tungsten, graphite, molybdenum, lead, hydropower potential

- $\quad$ Agriculture, including forestry and fisheries: Products - rice, vegetables, fruit, root crops, barley, cattle, pigs, chickens, milk, eggs, fish. Arable land $-16.5 \%$ of land area

- Industry: Types - electronics and electrical products, telecommunications, motor vehicles, shipbuilding, mining and manufacturing, petrochemicals, industrial machinery, steel

- $\quad$ Trade (2007): Exports - \$379 billion f.o.b.: electronic products (semiconductors, cellular phones and equipment, computers), automobiles, machinery and equipment, steel, ships, petrochemicals. Imports \$349.6 billion f.o.b.: crude oil, food, machinery and transportation equipment, chemicals and chemical products, base metals and articles. Major markets (2007) - China (25.7\%), U.S. (12.3\%), Japan (6.8\%), Hong Kong (4.5\%). Major suppliers (2007) - China (16.7\%), Japan (16.4\%), U.S. (10.5\%), Saudi Arabia (6.3\%), U.A.E. (4.2\%)

- The work force is comprised of 24.22 million individuals (75.2\% services, $17.3 \%$ industry, $7.5 \%$ agriculture)

- $\quad$ Currency: The currency is the won (South Korea, 2008).

\section{TRIP ACTIVITIES}

The trip took place in March and the format consisted of flying into Incheon, and traveling to Seoul, Pohang, Ulsan, Kori, Gyeongju, Seoul, and back to the airport at Incheon by van. Each of the businesses and cultural activities will be described after the itinerary.

\section{Itinerary:}

- Day 1: Flew into Incheon Korea arriving in the early evening and were transported to the hotel in Seoul.

- Day 2: Visited KEPCO (Korean Electric Power Company), lunch at the "Korean Chinese" restaurant, visited Gyeongbokgung Palace, visited Changgyeonggung Palace and Botanical Gardens, went to Insadong Street for tea, Korea House Restaurant for dinner, back to the hotel.

- $\quad$ Day 3: Seoul to Pohang on mini van, lunch at Silk Road Restaurant in the service center at Geumgangwnch, toured manufacturing facility at POSCO Steel Mill at Pohang, took the van to Ulsan, dinner at the hotel in Ulsan. Slept on traditional mat on heated floor.

- Day 4: Toured Hyundai Automotive, toured Hyundai Heavy Industries, then the hotel for lunch, toured Kori Nuclear Power Plant, took the van to Gyeongju, dinner at SuSuk Jung, checked into the hotel at Gyeongju.

- Day 5: Breakfast at the hotel in Gyeongju, Sonje Art Museum, Bulguksa Temple, drove up mountain to Seokguram Grotto, Korean Village (crafts, potter), lunch at Lee Jo in Gyeongju, Flying Cloud Tomb in Gyeongju, van to Seoul, back to the hotel in Seoul.

- Day 6: KEPCO, Korean Development Bank, lunch at club, Korean National Museum, Electronics Mart, back to hotel.

- $\quad$ Day 7: Up early to go to Incheon to return to the United States. 


\section{Description of Businesses Visited:}

- $\quad$ KEPCO: The only electric utility provider in Korea, KEPCO is an integrated electric utility company that is engaged in the transmission and distribution of electricity in Korea. As of December 31, 2007, the company and its generation subsidiaries owned approximately $88.3 \%$ of the total electricity generating capacity in Korea (excluding plants generating electricity primarily for private or emergency use). During the year ended December 31, 2007, KEPCO sold 369 billion kilowatt-hours of electricity. Of the 386 billion kilowatt-hours of electricity KEPCO purchased in 2007, 37.9\% was generated by Korea Hydro \& Nuclear Power Co., Ltd., its wholly owned nuclear and hydroelectric power generation subsidiary. The Company also wholly owns its five non-nuclear generation subsidiaries: Korea South-East Power Co., Ltd (KOSEP), Korea Midland Power Co., Ltd. (KOMIPO), Korea Western Power Co., Ltd. (KOWEPO), Korea Southern Power Co., Ltd. (KOSPO) and Korea East-West Power Co., Ltd. (EWP) (KEPCO Financial Summary, 2007).

- $\quad$ POSCO Steel Mill: Founded in 1968, POSCO began production in 1972, becoming the first modern steel plant in South Korea. POSCO's products include hot rolled steel, steel plate, wire rod, cold rolled steel, electrical steel and stainless steel. Of major interest is the role POSCO played in the economic development of Korea in the 1960s and 1970s; Korea's economy flourished with the growth of POSCO. By 1998, POSCO led the world in production of crude steel and was at the top of the world steel industry. POSCO was privatized in 2000 and is expanding its production base in overseas countries such as Vietnam and India, building integrated steel mills (POSCO, 2009).

- Hyundai Motor Company: Established in 1967, Hyundai Motor Company is South Korea's largest and the world's fifth largest automaker in terms of units sold per year. With headquarters in Seoul, Hyundai operates the world's largest integrated automobile manufacturing facility in Ulsan, Korea, which can produce 1.6 million units annually (Hyundai Motor Company, 2009)

- $\quad$ Hyundai Heavy Industries. ,Headquartered in Ulsan, South Korea, HHI is the world's largest shipbuilder and is a major builder of Flotaing Production Storage and Offloadoing vessels, and is one of the fastest growing companies in construction equipment. HHI produces tankers, bulk carriers, containerships, and gas and chemical carriers (Hyundai Heavy Industries, 2009).

- $\quad$ Kori Nuclear Power Plant: Kori Nuclear Power Plant is a South Korean nuclear power plant located in Gori, a suburban village of Busan. Owned and operated by KEPCO, the first reactor began operations in 1978, and there are plans to build two more reactors on site: Shin-Kori reactors (Kori Nuclear Power Plant, 2008).

- $\quad$ Korea Development Bank: According to Governor Min, "Founded in 1954, KDB has fulfilled its role as a state-owned bank by spearheading the nation's industrial and economic development for over five decades. The Bank has driven remarkable growth throughout the course of industrialization in Korea (Governor's Message, http://www.kdb.co.kr). Governor Min contends that the bank made a significant contribution to the country's recovery from the Asian financial crisis by leading in the restructuring ailing companies, and has recently expanded their operations to encourage innovative SMEs and venture companies, assisting balanced national development and expanding future growth. The government plans to privatize KDB to transform into a global investment bank under a Corporate and Investment Bank structure (KDB, 2008).

\section{Cultural Attractions Visited:}

- $\quad$ Gyeongbokgung Palace: Located in located in northern Seoul, Gyeongbokgung Palace was the main and largest palace of the Joseon Dynasty and one of the five grand palaces built by the Joseon Dynasty. It was in 1395, three years after the Joseon Dynasty was founded by Yi Seong-gye, when the construction of the main royal palace was completed and the capital of the newly founded dynasty moved from Gaeseong to Seoul. The palace was named Gyeongbokgung, the "Palace Greatly Blessed by Heaven." The government ministry district and main buildings of Gyeongbokgung Palace formed the heart of the capital city of Seoul 
and represented the sovereignty of the Joseon Dynasty. After being razed by the Japanese during the Hideyoshi invasions of 1591-1598, Gyeongbokgung Palace was left derelict for the next 250 years and was reconstructed in 1868 by the order of the Price Regent (Gyeongbokgung Palace, 2009).

- $\quad$ Changgyeonggung Palace and Botanical Gardens. Changgyeonggung Palace in Seoul was originally built by King Sejong as a residence for his father, Taejong, and was called Suganggung Palace. It was renovated and enlarged in 1483 by King Seongjong to be used as a residence for three dowager queens, at which time the name was changed to Changgyeonggung. It was also called Donggung, or East Palace along with Changdeokgung, which stood on the other side of the wall. (These two palaces played complementary roles.) During the colonial period, the Japanese renamed it Changgyeongwon, demoting it from a gung (palace) to a won (park), in an attempt to diminish the authority of the Korean royal family, and built a zoo, a botanical garden, and the royal Yi Household Museum on the site. In 1983, the zoo and botanical garden were moved, and the palace was renamed Changgyeonggung (Changgyeonggung Palace and Botanical Gardens, 2009).

- $\quad$ Insa-dong Street, Seoul Korea. Insadong Street is a major tourist street near the Anguk Subway or Metro station in Seoul Korea. The street is lined with traditional Korean vocalizations in the street, proper Korean meals, traditional tea houses, and traditional Korean fine crafts, all in one place (Insa-dong Street, 2008).

- $\quad$ Korea House Restaurant. This restaurant in Seoul features traditional Korean food and offers traditional Korean music and dancing after dinner.

- $\quad$ Gyeongju, Korea. This city is known as the "museum without wall" and houses numerous historical sites and relics and is one of the most important ancient cities of the world. The city has many royal tombs, museums, temples, monuments and houses a large collection of relics from the Silla period in the Gyeongju National Museum (Gyeongju, 2009).

- $\quad$ Seokguram Grotto. Located on Mt. Tohamsan in Gyeongju-si, as part of the Bulguksa temple complex and is the representative stone temple of Korea. The grotto overlooks the Sea of Japan and rests 750 meters above sea level and exemplifies some of the best Buddhist sculptures in the world (Seokguram Grotto, 2009).

- $\quad$ Artsonje Museum. Situated in the Gyeongju Bonum complex in Gyeongju, this is a private contemporary art museum which organizes exhibitions showing major contemporary artworks from its collection. The Artsonje Museum collection consists of 450 pieces including sculptures, paintings, and photographs from Europe and the United States from the 1960's and major Korean Modern art from the 1970's (http://www.artsonje.org/gye/eng/e_about.asp).

- $\quad$ Cheonmachong Tomb. Gyeongju houses 23 large tombs in the Daereung-won Tumuli Park, one of the most famous of which is the Cheonmachong Tomb (Flying Cloud Tomb). The inside of this tomb houses 11,526 remains and crowns of an unknown king from the Silla Kingdom, demonstrating the lavish lifestyle of the king (http://asiaenglish.visitkorea.or.kr).

- $\quad$ National Museum of Korea. In Seoul, the National Museum of Korea is the flagship museum of Korean history and art in South Korea and is the cultural organization that represents Korea. The museum contains over 150,000 pieces in its collection with 11,000 on display at one time. Divided into three floors, the left of the museum is supposed to represent the past while the right side of the museum represents the future. Different sections of the museum include the Archaeological Gallery, the Historical Gallery, Fine Arts Gallery I and II, Asian Arts Gallery, and the Donation Gallery (National Museum of Korea http://www.museum.go.kr/eng/). 


\section{POST TRIP ACTIVITIES}

This section covers incorporating class applications of concepts experienced during the trip. While possible classroom applications cover all business disciplines, this paper will focus on the following Management applications: Geert Hofstede's $(2003,2001,1991)$ framework for assessing national cultures, vertical integration, joint ventures with local partners, core competencies, Hamal \& Prahalad's Core Competencies Matrix, value chain activities/management, Porter's Diamond of National Advantage, and Organizational Behavior and Human Resource Management implications. The most extensive example used will be that of Geert Hofstede's National Cultural Dimensions.

\section{Geert Hofstede's National Cultural Dimensions.}

Geert Hofstede's $(2003,2001,1991)$ framework for assessing cultures is one of the most widely cited approaches for helping managers understand differences between national cultures. In his research he found that managers and employees vary on five dimensions of national culture: (1) individualism vs. collectivism, (2) power distance, (3) uncertainty avoidance, (4) achievement versus nurturing, and (5) long-term and short-term orientation. Each dimension will be described below, followed by a comparison of the scores of South Korea and the United States.

"Individualism vs. Collectivism" concerns the extent to which people in a country prefer to act as individuals or as members of groups. Individualism is the degree to which people tend to act as individuals while collectivism is characterized by a social framework in which people prefer to act as members of groups. According to Hofstede, (2003) "on the individualist side we find societies in which ties between individuals are loose: everyone is expected to look after him/herself and his/her immediate family. On the collectivist side, we find societies in which people from birth onwards are integrated into strong cohesive in-groups, often extended families which continue protecting them in exchange for unquestioning loyalty" (p. 2-3).

South Korea has a low Individualism (IDV) score of 18, indicating that the society is collectivist as compared to individualist. Hofstede contends that this is manifested in a close long-term commitment to the member group, such as a family, extended family, or extended relationships. Loyalty in a collectivist culture is of utmost importance and over-rides most other societal rules and regulations. This culture promotes strong relationships where everyone takes responsibility for fellow members of their group. Conversely, the United States is one of only 7 countries in the Hofstede research that has Individualism as their highest dimension: 91. "The high Individualism ranking indicates a society with a more individualist attitude and relatively loose bonds with others. The populace is more self-reliant and looks out for themselves and their close family members (Hofstede, 2003, p. 2 $-3)$.

The second dimension, "power distance," is a measure of the extent to which society accepts the fact that power in organizations is distributed unequally. High power distance societies tend to accept inequalities while low power distance societies play down inequities. South Korea has a Power Distance score of 60 while the United States has a score of 40 (world average $=55$ ). "This indicates that the United States has greater equality between societal levels, including government, organizations, and even within families. This orientation reinforces a cooperative interaction across power levels and creates a more stable cultural environment" (Hofstede, 2003, p. 2).

"Uncertainty avoidance," the third dimension, is the degree to which people tolerate risk and prefer structured over unstructured situations. Low uncertainty avoidance societies are comfortable with risks while high uncertainty avoidance societies feel threatened by uncertainty and ambiguity. The United States had a score of 46, Korea had a score of 85 and the world average was 64 . The United States' low ranking indicates "a society that has fewer rules and does not attempt to control all outcomes and results. It also has a greater level of tolerance for a variety of ideas, thoughts, and beliefs" (Hofstede, 2003, p. 3) Of the five dimensions, South Korea's highest score is in "uncertainty avoidance" indicating the society's low level of tolerance for uncertainty. In an effort to minimize or reduce this level of uncertainty, strict rules, laws, policies, and regulations are adopted and implemented. The ultimate goal of this population is to control everything in order to eliminate or avoid the unexpected. As a result of this high Uncertainty Avoidance characteristic, the society does not readily accept change and is very risk adverse. 
The fourth dimension, "Masculinity vs. Femininity" refers to the distribution of roles between the two genders. Women's values differ less among societies than men's values. Men's values contain a dimension ranging from very assertive and competitive to modest and caring. The assertive pole is termed masculine while the modest pole is termed feminine. The United States had a ranking of 62, compared to Korea's ranking of 39 and the world average was 50. According to Hofstede (2003), "this indicates the country experiences a higher degree of gender differentiation of roles. The male dominates a significant portion of the society and power structure. This situation generates a female population that becomes more assertive and competitive, with women shifting toward the male role model and away from their female role" (p. 3). "The women in feminine countries have the same modest, caring values as the men; in the masculine countries they are somewhat assertive and competitive, but not as much as the men, so that these countries show a gap between men's values and women's values" (Hofstede, 2003, p. 3).

"Long term and short term orientation," the fifth dimension, refers to a country's orientation toward life and work. Countries with a long-term orientation look to the future and value thrift and persistence. Countries with a short term orientation, such as the United States with a score of 29 , have respect for tradition, fulfilling social obligations, and protecting one's face. The short term orientation for the United States is the lowest Dimension for the U.S. (29) compared to the world average of 45, and a South Korean score of 70. The long term orientation of South Koreans indicates values of thrift and perseverance (Hofstede, 2003, p. 3)

Figure 1 presents Hofstede's 5 dimensional model comparing the scores of South Korea and the United States. Students then discuss implications for South Korean companies opening up manufacturing facilities in the United States and vice versa.

Figure 1: Hofstede's Dimensions for South Korea and the United States

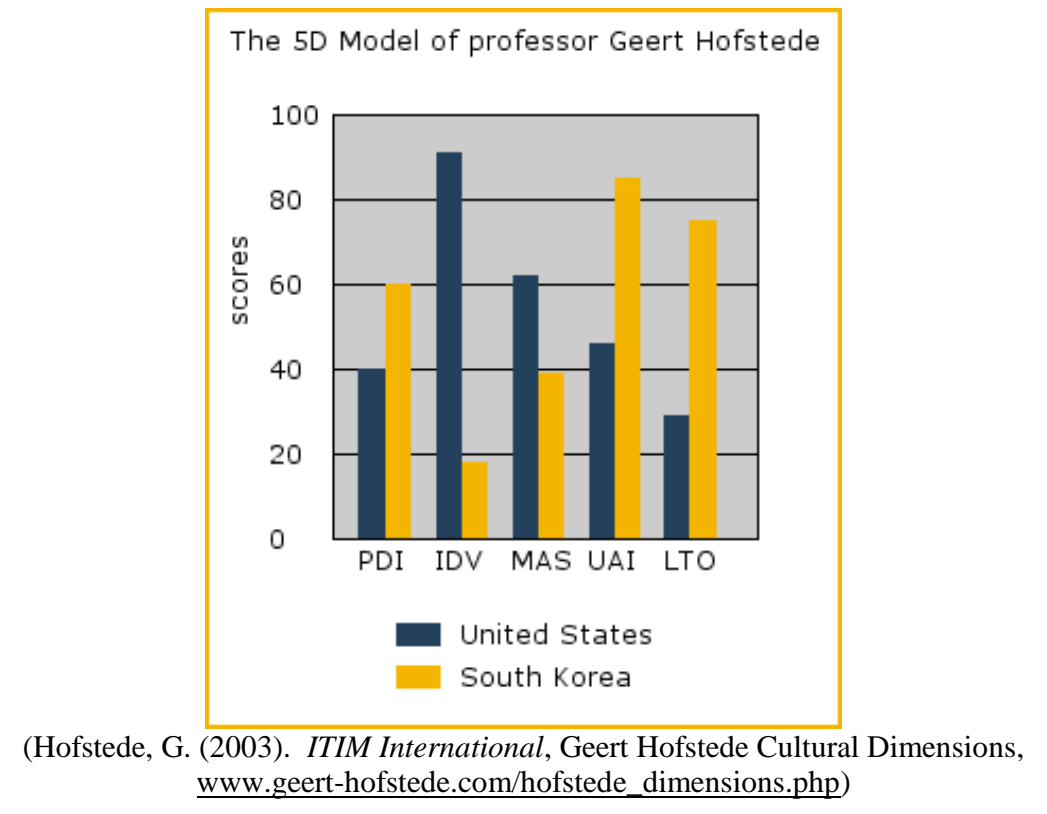

The Korean Electric Power Company (KEPCO) is an excellent example to use to explain the following concepts: Vertical integration, joint ventures with local partners, Hamal \& Prahalad's Core Competencies Matrix, and value chain activities/management.

\section{Vertical Integration}

The vertical integration strategy involves an organization growing by gaining control of its inputs (backward), its outputs (forward), or both. In backward vertical integration, the organization gains control of its 
inputs or resources by becoming its own supplier. In forward vertical integration, the organization gains control of its outputs (products or services) by becoming its own distributor. This is a growth strategy because an organization is expanding its operations and activities by becoming a source of supply or a source of distribution (Coulter, 2008).

\section{Joint Ventures}

In a joint venture, two or more separate organizations form a separate independent organization for strategic purposes. Joint ventures are often used when the partners do not want to or cannot legally join together permanently; instead, the partners create a separate entity to do their business activity together. This is a popular partnering method in international growth because it minimizes the financial and political-legal constraints that go with mergers-acquisitions and internal development (Coulter, 2008).

\section{Core Competencies}

These are the skills and abilities by which resources are deployed through an organization's activities and processes to achieve a competitive advantage in ways that others cannot imitate or obtain (Johnson, Scholes, \& Whittington, 2008).

\section{Hamal \& Prahalad's Core Competencies Matrix}

In many companies the corporate identify is built around the concept of strategic business units and not around core competencies. Hamel and Prahalad feel that this is not a good reflection of an organization and that a strong end focus should be supplemented by an equally important view of the organization's core competencies. Therefore, in their book "Competing for the Future," they designed a matrix to help in setting specific acquisition and deployment goals, based on the organization's core competencies (Hamel-Prahalad Matrix, 2006). Figure 2 presents the matrix and provides a visual example of how KEPCO's competencies can be used as examples for entering new markets and developing new competencies.

Figure 2: The Hamel \& Prahalad Matrix

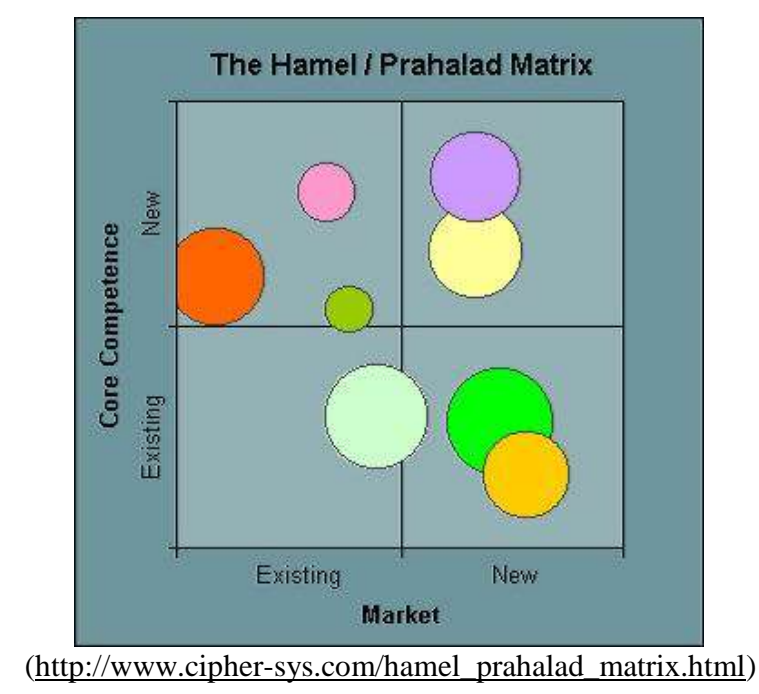

\section{Value Chain Management}

This is "the process of managing the sequence of activities and information along the entire value chain. In contrast to supply chain management, which is internally oriented and focuses on efficient flow of incoming materials (resources) to the organization, value chain management is externally oriented and focuses on both 
incoming materials and outgoing products and services" (Robbins \& Coulter, 2009, p. 430). KEPCO illustrates all of the primary activities (R\&D, Production, Marketing \& Sales, Service) and the support activities (firm infastructure, human resource management, technology development, procurement) of the value chain.

\section{Porter's Diamond of National Advantage}

For any strategy, internationalization needs to be based on possession of some sustainable competitive advantage. A foreign entrant must have significant competitive advantages to overcome the disadvantages as they relate to the home market (superior market knowledge, established relationships with local customers, strong supply chains, etc.). The internalization context raises specific national sources of advantages that can be substantial and hard to imitate. Micheal Porter's (1990) "Diamond of National Advantage" helps explain why some nations tend to produce firms with sustained competitive advantages in some industries more than others. The four factors in this theory are (1) factor conditions, (2) home demand conditions, (3) related and supporting industries, and (4) firm strategy, industry structure, and rivalry. The combination of the steel industry (POSCO Steel Mill), Hyundai Automotive, and Hyundai Heavy Industries provide an excellent example of these four factors for Porter's Diamond.

\section{Organizational Behavior and Human Resource Management Implications}

Employee recruitment and selection, training processes, performance appraisal, seniority and job security are all issues that can be explored in the classroom when discussing the differences between traditional Korean practices and those of the United States.

\section{SUMMARY}

This paper provides an approach that smaller colleges and universities can use to meet accreditation standards to internationalize their curriculum and incorporate active learning into the curriculum. While South Korea was used as the example, the approach is applicable to other countries as well.

\section{AUTHOR INFORMATION}

Donald R. (Don) Self is Distinguished Teaching Professor and Lowder/Weil Chair at Auburn University Montgomery (USA). He received the DBA degree from Louisiana Tech University in 1977 and has been a university teacher since 1970. He has received various teaching and research awards including the SherwinWilliams Distinguished teaching award from the Society of Marketing Advances.

Don served ten years as the founding editor of the Journal of Non-profit and Public Sector Marketing and served as Associate Editor of the Journal of Marketing and the Journal of Professional Selling and Sales Management. He has edited or co-edited seven books.

Dr. Robin Self, Professor of Management, has been a member of the Alabama State University faculty since 1991. She has degrees from the University of Georgia (BA - Communications 1978, MA - Communications 1981) and Georgia State University (Ph.D. - Management, 1991). Prior to joining Alabama State University, she taught at the University of Georgia and Georgia Southern University. Dr. Self has over 30 articles and conference papers in the areas of organization commitment and socialization, health care marketing, strategy, and culture including publications in the Journal of Applied Psychology, Journal of Management, Journal of Managerial Issues, and Health Marketing Quarterly. She has received several awards for teaching and research.

\section{REFERENCES}

1. AACSB International Eligibility Procedures and Accreditation Standards for Business Accreditation. (2008), p. 15, http://www.aacsb.edu/accreditation/standards.asp.

2. ACBSP Standards and Criteria for Demonstrating Excellence in Baccalaureate/Graduate Degree Schools and programs. (2008), p. 39, www.acbsp.org.

3. Bammel, S. (2003a). Korean Greeting and Introductions Cincinnati, OH: At Ease, Inc. 
4. Bammel, S. (2003b). Korean Gift-Giving, Cincinnati, OH: At Ease, Inc.

5. Bammel, S. (2003c). Korean Business Card Exchange, Cincinnati, OH: At Ease, Inc.

6. Bammel, S. (2003d). Korean Business Meetings, Cincinnati, OH: At Ease, Inc.

7. Bammel, S. (2003e). Korean Business Conversation, Cincinnati, OH: At Ease, Inc.

8. Bammel, S. (2003f). Korean Social Interaction, Cincinnati, OH: At Ease, Inc.

9. Bammel, S. (2003g). Korean Drinking Etiquette, Cincinnati, OH: At Ease, Inc.

10. Bammel, S. (2003h). Korean Table Manners, Cincinnati, OH: At Ease, Inc.

11. Business and International Education Program. Retrieved from http:www.ed.gov/programs/iegpsbie/index.html).

12. California College of International Education. Retrieved from http://ccieworld.org/curriculum.htm.

13. Changgyeonggung Palace and Botanical Gardens. (2009). Retrieved from www.visitseoul.net.

14. Coulter, M. (2008). Strategic Management In Action ( $4^{\text {th }}$ edition). Prentice Hall: Upper Saddle River New Jersey.

15. Gyeongbokgung Palace. (2009). Retrieved from http://www.royalpalace.go/kr/html/eng/main/main.jsp.

16. FIPSE Home Page. ( 2009, February 20). Office of Postsecondary Education, Retrieved from http:/www.ed.gov/about/offices/list/ope/fipse/index.html.

17. Gyeongju. ( 2009). Retrieved from: http://my.snu.edu/worldguide/wta/fea/kyo.html.

18. Hamel-Prahalad Matrix. (2006). Cipher Research Consulting Services for Business Professionals. Retrieved from http://www.cipher-sys.com/hamel_prahalad_matraix.html.

19. Hofstede, G. (1991). Cultures and Organizations. McGraw-Hill: London.

20. Hofstede, G. (2001). Culture's Consequences. Thousand Oaks, CA: Sage Publications.

21. Hofstede, G. (2003). ITIM International, Geert Hofstede Cultural Dimensions, www.geerthofstede.com/hofstede_dimensions.php.

22. Hyundai Automobile Company. (2009). Retrieved from http://www.wikpedia.org/wiki/Hyiundai Motors.

23. Hyundai Heavy Industries. (2009). Retrieved from English.hhi.co.kr/Business/Shipbuilding.asp.

24. Insa-dong Street. (2008). Retrieved from http://wwww.virtualtourist.com/travel/Asia/South_Korea.

25. Johnson, G., Scholes K., \& Whittington, R. (2008). Exploring Corporate Strategy ( ${ }^{\text {th }}$ ed). Financial Times Press.

26. KEPCO Financial Summary. (2007). Retrieved from http://www.google.com/finance?q=NYSE:KEP.

27. KDB. ( 2008). Governor's Message, Retrieved from http://www.kdb.co.kr.

28. Kori Nuclear Power Plant. (2008, December 15). Retrieved from http://en.wikipedia.org/wiki/Kori_Nuclear_Power_Plant).

29. Loughrin-Sacco, S. (1998). Funding Sources for International Business. Retrieved from www.cudenver.edu/International/CIBER/Documents/Funding.

30. Porter, Michael, (1990). The Competitive Advantage of Nations. MacMillan.

31. POSCO. (2009). Retrieved from http://www.posco, com/homepage.

32. Robbins, S., \& Coulter, M. (2009). Management $\left(19^{\text {th }}\right.$ edition). Prentice Hall.

33. SIEU Travel Abroad (2009) Checklists for Faculty Preparing to Take Students Abroad, Retrieved from http://www.siue.edu/international/octravel/Checklist.shtml.

34. Seokguram Grotto. (2009). Retrieved from http://english.visitkorea.or.kr.

35. Southern Illinois University Edwardsville. Retrieved from http://www.siue.edu/international/octravel/Checklist.shtml.

36. South Korea. (2008, October). U. S. Department of State Diplomacy in Action, Retrieved from http://www.state.gov/r/pa/ei/bgn/2800.htm.

37. Title VI, (2008, August 12), International Education Programs Service, Retrieved from http://www.ed.gov/about/offices/list/ope/eigps/title-six.html.

38. Title VI Education Act. Retrieved fromwww.ed.govv.

39. University of Pittsburg, Retrieved from http://www.business.pitt.edu/ibc/academics/curriculum-developmentgrant.php. 